\title{
The Efficiency of Polymeric Coatings for the Conservation of Ancient Egyptian Wall Paintings, El-Qurna Necropolis, Upper Egypt
}

\author{
Hussein Hassan Marey Mahmoud
}

\begin{abstract}
The present work aims at studying the long-term protection of damaged Egyptian wall paintings (tomb of Ameneminet, No. TT277, Ramesside Period), El-Qurna necropolis, Upper Egypt. To achieve this, the efficiency of some polymeric materials for the consolidation of laboratory samples similar to the ancient murals was evaluated. The climatic conditions of the area play an important role in accelerating the damages process of the paintings. Crystallization cycles of salts exert additional pressure by producing cracking, powdering and flaking, in addition to pulverization of the pictorial layers. Different commercial products based on acrylic and silicone consolidation materials were tested in this study. The evaluation of the consolidation process was performed using the visual observation, scanning electron microscopy (SEM), contact angle values, color measurements and determining the physical and mechanical properties. The results showed that the superior behavior of water repellency was obtained by the micro emulsion Wacker VP 1311. Moreover, the application of the stone strengthener Wacker $\mathrm{OH}$ and the acrylic co-polymer Paraloid B82 helped in improving the physical and mechanical properties of the treated samples. In conclusion, Wacker $\mathrm{OH}$ could be used to enhance the durability of the inner matrix; however, the application of the microemulsion Wacker VP 1311 as a protective layer will increase the material's water repellency in areas subjected to moisture or ground water attack.
\end{abstract}

Keywords: Wall Paintings; El-Qurna Necropolis, Polymeric Coatings; SEM; Color Measurements.

La eficacia de los revestimientos poliméricos para la conservación de pinturas murales del antiguo Egipto, necrópolis de El-Qurna, Alto Egipto

Resumen: El objetivo del trabajo es el estudio para la protección en el tiempo de las pinturas murales alteradas de la tumba de Ameneminet, $n^{\circ}$ TT277, del Período Ramésida, en la necrópolis de El-Qurna, Alto Egipto. Con este fin se ha testado la eficacia de materiales poliméricos para la consolidación sobre una serie de muestras en el laboratorio, preparadas de forma similar a las pinturas originales. Las condiciones climáticas del lugar desempeñan un importante papel acelerando los procesos de deterioro de las pinturas. Los ciclos de cristalización de sales ejercen también una presión adicional produciendo craqueladuras, pulverulencia y descamaciones en los revestimientos pictóricos. Diferentes productos comerciales consolidantes de tipo acrílico y silicónico han sido testados durante el estudio. La evaluación del proceso de consolidación se ha realizado mediante examen visual, microscopía electrónica de barrido (SEM), evaluación del ángulo de contacto, mediciones de color y determinación de las propiedades físicas y mecánicas. Los resultados muestran que el mejor comportamiento hidrorepelente se obtiene con una microemulsión Wacker VP 1311. Sin embargo, la aplicación del consolidante para piedra Wacker $\mathrm{OH}$ y del copolímero acrílico Paraloid B-82 ayudan en la mejora de las propiedades físicas y mecánicas de las muestras tratadas. En conclusión, el producto Wacker $\mathrm{OH}$ puede utilizarse para el tratamiento del soporte alterado, mientras que la aplicación de la microemulsión Wacker VP 1311 como capa de protección, incrementa la hidrorepelencia de las superficies expuestas a la humedad o a la ascensión capilar.

Palabras clave: Pinturas murales; Necrópolis El-Qurna; Revestimientos poliméricos; SEM; Medidas de color.

\section{A eficiência de revestimentos poliméricos para a conservação de antigas pinturas egípcias, El-Qurna Necropolis, no Alto Egito}

Resumo: $O$ presente trabalho tem como objetivo estudar a protecção, a longo prazo, das danificadas pinturas egípcias (túmulo de Ameneminet, No. TT277, Período Ramesside), El-Qurna necrópole, Alto Egito. Para alcançar isso, foi avaliada a eficiência de alguns materiais poliméricos para a consolidação de amostras labo- 
ratoriais semelhantes aos antigos murais. As condições climáticas da região têm um papel importante na aceleração do processo de degradação das pinturas. Ciclos de cristalização de sais exercem uma pressão adicional, através da produção de estalados, de pulverização e destacamento, além da pulverização das camadas pictóricas. Diferentes produtos comerciais, à base de materiais de consolidação acrílicos e de silicone, foram testados neste estudo. A avaliação do processo de consolidação foi realizada através da observação visual, de microscopia eletrónica de varrimento (SEM), de valores de ângulos de contacto, medidas de cor e determinação das propriedades físicas e mecânicas. Os resultados mostraram que o comportamento superior de repelência à água foi obtido pela micro emulsão Wacker VP 1311. Além disso, a aplicação da pedra fortalecedora Wacker OH e do co-polímero acrílico Paraloid B82 ajudou a melhorar as propriedades físicas e mecânicas das amostras tratadas. Em conclusão, a Wacker $\mathrm{OH}$ pode ser uitlizado para melhorar a durabilidade da matriz interior, no entanto, a aplicação da microemulsão Wacker VP 1311, como camada protectora, aumentará a repelência à água do material, em áreas sujeitas a humidade ou água subterránea

Palavras-chave: Pintura mural; El-Qurna Necropolis; Camadas poliméricas; SEM; Medições de cor.

\section{Introduction}

El-Qurna necropolis is located in the west bank of the river Nile at the city of Luxor (about $670 \mathrm{~km}$ south of (airo). There are more than three hundred tombs belong to officials of the New Kingdom (c.1570-1070 BC) at El-Qurna necropolis (Kamil 1976). The tombs style is the cut-rock tombs in the bedrock of the Thebes Mountains. Thebes Mountains are composed of 350 meter thick Eocene marls and limestone overlying the 60 meter thick Esna shale Formation. The lower levels of the Theban Formation are composed of slightly clayey, sub-chalky limestone, which serves to enclose a few bedrock layers of flint nodules and becomes more massive at greater depths (Said 1960; Guillaume and Piau 2003). The biggest hazard to the area is the flood water that penetrates into the structures. Furthermore, the deterioration becomes more effective due to the presence of swelling clay minerals and soluble salts in the geological structure. Moreover, the water seepage from the nearby houses and the cultivated lands represent another source of saline ions which react with stone material and re-crystallize in form of different salt phases (Marey Mahmoud 2010). The decorations of the ancient tombs in Egypt are expected undergo as a result of the environmental effects, mainly, salt weathering, thermal and wet-dry cycling, in addition to the biodeterioration. Crystallization of salts is the main deterioration factor affecting in the site, crystallization of salts produces a destructive effect. Under favorable conditions, some salts may crystallize or recrystallize to different hydrates which occupy a larger space and exert additional pressure producing cracking, powdering and flaking (Rodríguez-Navarro and Doehne 1999; Pel et al. 2002) (see Figure 1). The same salt may crystallize as isometric grains in crusts and as whiskers in fluffy efflorescence at different places on a wall at the same time or at the same place at different times (Arnold and Zehnder, 1987). A serious damage of pigments could be produced by the effect of salt ions. Chlorine plays a dominant role in the light induced blackening phenomenon of vermilion. Under the influence of light, an electron hole pair is generated and a photo-electrochemical process takes place, which enables an electron transfers from chlorine anion to mercury and from sulphide back to chloride (i.e. chlorine has a catalytic function) (Keune and Boon 2005). Moreover, damage of the wall paintings produced by swelling clays and particularly in the presence of salts is mainly resulting in form of detachments, disintegration of the inner structure and micro/macro cracks on the painted surfaces.

In general, many studies have been devoted to study stone consolidation materials and their efficiency to strengthen the stone matrix (Clifton and Frohnsdorff 1982; Chiari et al. 1992; Brus and Kotlik 1996; Grissom 1999; Robert et al. 2004; Cnudde et al. 2007; Favaro et al. 2007; Ahmadi 2008; Rizzo 
et al.2009; Xu et al. 2012). The main objective of this study was to evaluate the efficiency of some polymeric coatings based on acrylic and silicone products used to increase the durability of the damaged stones and to improve their resistance to water attack. The analysis performed on several damaged limestone samples collected from the tomb of Ameneminet, TT277, El-Qurna necropolis, Upper Egypt showed that the main dominant salts affecting in the site are sodium chloride (halite, $\mathrm{NaCl}$ ) and phases of sulphates [gypsum, $\mathrm{CaSO}_{4} \cdot 2 \mathrm{H}_{2} \mathrm{O}$; bassanite, $\mathrm{CaSO}_{4} \cdot 0.5 \mathrm{H}_{2} \mathrm{O}$ and anhydrite, $\mathrm{CaSO}_{4}$ ]. To evaluate the success of the consolidation process, different analytical methods were used such as: visual observation, scanning electron microscopy (SEM), contact angle values, and the color measurements. The results will be used in the conservation-restoration interventions of the murals.
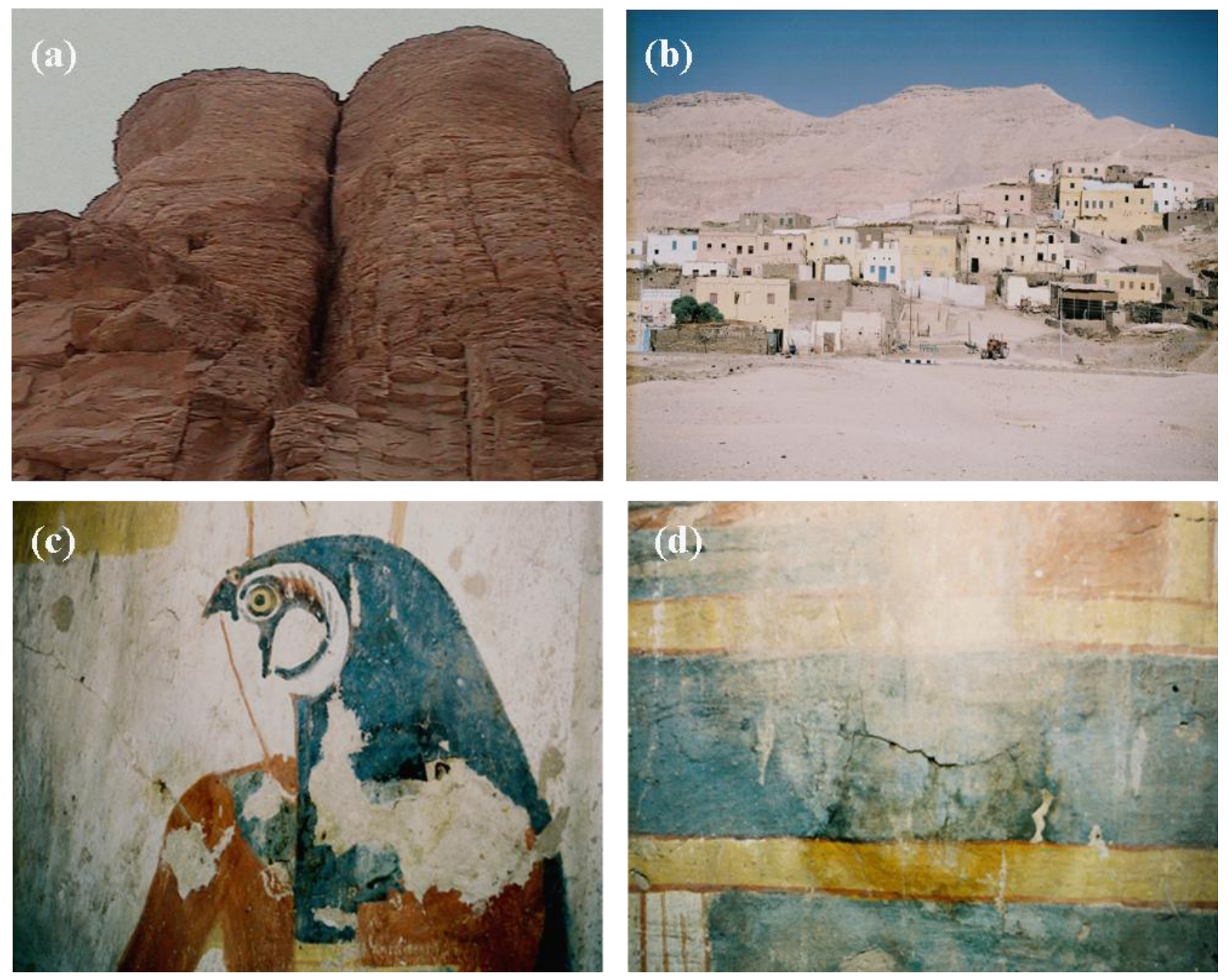

Figure 1. (a) View of the Theban Mountain, El-Qurna necropolis. (b) View of Qurnet Marai necropolis. (c) Loss of the paints and painted flakes express the state of conservation of the wall paintings at Tomb of Ameneminet, No. TT277. (d) Different cracks spread over the painted surfaces.

\section{Consolidation materials}

Where stone is severely weakened by decay, some form of consolidation may be necessary to restore some strength. The treated stone will need to have much the same moisture expansion, thermal expansion, and elastic modulus as the untreated stone, in order to avoid internal stresses. Ideally, the treatment should work equally well on any type of stone, regardless of the cause of decay (Price 1996). Consolidation materials are applied as liquids or emulsions but, to be effective, 
they must cause a solid material to be laid down in the pores of the material. The initial properties of stone consolidants depend on many factors: the penetration of the consolidant into the substrate and its distribution within the substrate, the viscosity and surface tension of the liquid, and the contact angle of the liquid against surfaces within the material. Consolidation may result from solidification of the liquid within the pores, by polymerization of a monomer or cooling of a molten solid, or from evaporation of a volatile solvent from a solution of solid material, also result from nucleation and growth of relatively small quantities of solid from the liquid phase (Clifton and Frohnsdorff 1982).

\section{Silicone polymers}

The silicone polymer is a generic term which includes a large variety of different products/materials, gels, elastomers or resins (according to their state of reticulation, to the density of cross-links) (Robert et al., 2004). These include a wide variety of organosilicon compounds which polymerize to form networks of silica gel, as the gel dehydrates it forms deposits of silica in the substrate. Some types (e.g. tetraalkoxysilanes) have no water repellent properties; others (e.g. alkyl trialkoxysilanes) have a degree of water repellency which can be controlled by altering the properties of starting material. After hydrolysis and condensation, ethyl silicates originate colloidal silica deposits inside the porous structure (Chiari et al. 1992; Grissom et al. 1999; Delgado Rodrigues 2001). Recently, a particular attention was devoted to composites obtained by introducing nanoparticles of inorganic oxides into hybrid siloxane or silicone polymers, for example starting from tetraethoxysilane (TEOS) and colloidal fumed silica by a simple so-gel process (Manoudis et al. 2008).

\section{Silane-based materials}

Silane or $\mathrm{SiH} 4$ is also known as monosilane, silicane, and silicon tetrahydride. Silanes are considered to be analogues of alkanes, with the same structural formula: $\mathrm{SinH} 2 n+2$. For example, silane is similar to methane $(\mathrm{CH} 4)$. As with alkanes which undergo hydrolysis and form alkanols $(\mathrm{R}-\mathrm{OH})$, silanes produce silanols (-Si-OH). Two compounds have been dominant: methyltrimethoxysilane (MTMOS) and tetraethoxysilane (TEOS), in general, used under the form of oligomers. These consolidants are absorbed by the stone, hydrolyzed by water to form silanols that then polymerize in a condensation reaction and form a polymer that produces the required strength increase (Ferreira Pinto and Delgado Rodrigues 2008). Smaller molecular size allows silanes to penetrate deeper than siloxane molecules. Silane can be added to acrylic polymers to improve the properties of the new mixture such as (Raccanello E55050, Acrisil 201/ON0); these mixtures give the materials more durability to salt weathering (Brus and Kotlik 1996).

\section{Siloxanes}

Siloxanes, also known as oligomer silicone, are partially polymerized molecules that eventually will create a silicone resin. After evaporation of the solvent, hydrophobic organic groups (e.g. methyl or butyl) will show a water-repellence effect, caused by the fact that the methyl groups are non-polar functional groups (Cnudde et al. 2007). The advantages of coatings obtained from siloxanecontaining polymer matrices are the consequence of their ability to crosslink in situ after substrate treatment (Simionescu and Olaru 2009). Polysiloxanes are partially polymerized silanes; they are less volatile than silanes and are soluble in organic solvents. When polysiloxanes are applied on a polar surface, the polysiloxane molecules attach to the surface by their polar part and their nonpolar parts are on the outside. The non-polar parts do not absorb water; they act as water barriers 
and are called hydrophobic or water-repellent (Torraca 1988). Furthermore, alkoxysilanes are sold under different trade names such as Silester, a mixture of ethyl silicates, and Conservare $\mathrm{H}$, a mixture of partially polymerized alkoxysilanes and silicic ethyl esters.

\section{Acrylic Polymers}

Acrylic materials used in conservation are the polymers of acrylate and methacrylate. These compounds are derived from acrylic acid and methacrylic acid respectively. Acrylic materials are divided into three groups: resins in solution, acrylic emulsions, and acrylic colloidal dispersions (Amoroso and Fassina 1983; Horie 1997; Ahmadi 2008). Acrylic polymers can be mixed with each other to make copolymers with desirable properties. These polymers are known as "tailor-made polymers". For example, by adding ethyl acrylate or butyl methacrylate to methyl methacrylate, hardness, chemical strength and good weathering ability increase. Methyl methacrylate can harden the surface of a stone and effectively consolidate the stone if both deep penetration and complete polymerization are achieved (Favaro et al. 2007).

\section{Methods and techniques}

\section{Sampling}

The observation of the damaged walls of the studied tomb led to diagnose the main weathering forms such as blistering, disintegration of stone. Micro-samples of the different walls were carefully collected using a metallic scalpel, especially from the highly weathered areas.

\section{Scanning electron microscopy with an EDS microanalysis detector (SEM)}

The morphological characteristics of the archaeological and laboratory samples were determined by a JEOL JSM-840A scanning electron microscope. The accelerating voltage $20 \mathrm{kV}$, probe current $45 \mathrm{nA}$, the working distance $20 \mathrm{~mm}$ and the counting time $60 \mathrm{~s}$ real time. The matrix correction protocol was ZAF correction. The samples were coated with carbon, using a Jeol JEE-4X vacuum evaporator.

\section{$X$-ray diffraction analysis (XRD)}

The collected samples were grounded into powder in an agate mortar and studied by X-ray diffraction method (XRD) in order to determine their mineralogical composition. XRD analysis was performed using a Phillips PW1840 diffractometer with Ni-filtered Cu-ka radiation. The samples were scanned over the $3-63^{\circ} 2 \theta$ interval at a scanning speed of $1.2^{\circ} / \mathrm{min}$. Quantitative estimates of the abundance of the mineral phases were derived from the XRD data, using the intensity of a certain reflection, the density and the mass absorption coefficient for $\mathrm{Cu}$-ka radiation for the minerals present. Corrections were made using external standard mixtures of minerals. The detection limit was $\pm 2 \% \mathrm{w} / \mathrm{w}$.

\section{Contact angle measurements}

Contact angle values were measured by the use of Kruss G10 goniometer measuring system. Contact angle values were measured according to the literature of Manoudis et al. (2007). Equilibrium contact angles were measured as follows: droplets were delivered to the specimen and from a 
height sufficiently close to the substrate, so that the needle remained in contact with the liquid droplet. Then, the delivery needle was withdrawn with minimal perturbation to the drop and the image of the drop was captured immediately for contact angle measurement. The contact angle hysteresis was calculated by the dynamic sessile drop method. The advancing/receding contact angle was the maximum/minimum angle measured while the volume of the droplet was increased/decreased without increasing/decreasing the solid-liquid interfacial area.

\section{Visual observation and colorimetry}

In order to study how much the consolidation products changed the color of the treated surface, the visual observation according to (ASTM 1729) has been performed basing on the comparison between the treated samples and the standard ones to detect any change in the appearance. The colorimetric study was performed using a portable reflectance spectrophotometer MiniScan ${ }^{\circ} \mathrm{XE}$ Plus (HunterLab) and evaluated by the use of $L^{*} a^{*} b^{*}$ coordinates of the CIE 1976 scale. On a sample from each set, three different spots were examined. The color changes for each sample were measured over a period of time: two weeks after treatment and four weeks after the first reading. This will be continued to find out when the changes will reach a constant level.

\section{Determination of basic physical properties}

For the determination of basic physical properties, the archaeological and laboratory samples were dried in an oven at to constant weight. These weight measurements were recorded as the dry weights of the samples $\left(m_{\text {dry }}\right)$. The saturation of samples in water was carried out in a vacuum oven (Lab-line 3608-6CE Vacuum Oven). The weights of the water-saturated samples were recorded as saturated weights $\left(m_{\text {sat }}\right)$. The weight of saturated samples was also measured in water and recorded as the Archimedes weight $\left(m_{\text {arch }}\right.$ ) of the samples. All weights were measured with the sensitivity of $0.01 \mathrm{~g}$ and they were used in the calculation of the porosity and density of the sample. Then, vales of porosity, apparent density, real density and capillary water absorption were measured as recommended by RILEM (1980).

\section{Determination of Uniaxial Compressive Strength}

The determination of Uniaxial Compressive Strengths of bricks and mortars were measured by Shimadizu AG-I Mechanical Test Instrument. Samples were prepared by using a cutting machine (Discoplan-TS 372). The lumps of collected samples were cut into pieces with prismatic shapes with the minimum thickness of $30 \mathrm{~mm}$. Shimadzu AG-I Mechanical Test Instrument automatically computed, displayed and recorded test results using a software system. Maximum $15 \mathrm{kN}$ force was applied with $1 \mathrm{~mm} / \mathrm{min}$. speed. The strokes were recorded under loading. The relationship between the strokes and load by a graph was automatically displayed on the test condition monitor. This graph was composed of a curve whose peak point gave the 34 maximum force $(F)$ under which the specimen failed. As a result, uniaxial compressive strenghts represented by ' $\sigma$ ' were calculated by using this graph with the following formula:

$\sigma=\mathrm{F} / \mathrm{A}$

where;

F: Failure load (kN)

A: Area onto which loading was applied $\left(\mathrm{mm}^{2}\right)$ 

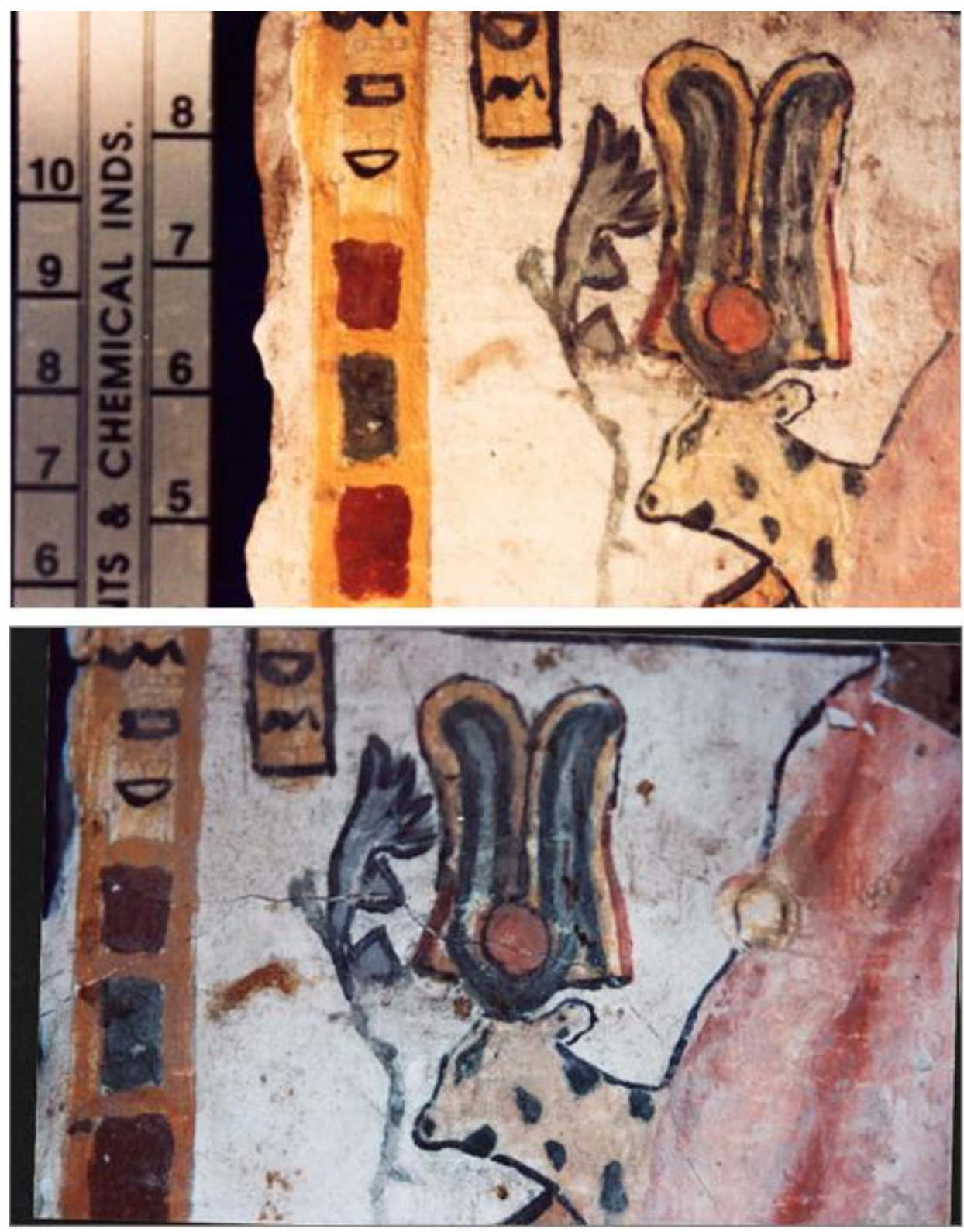

Figure 2. Laboratory models before and after artificial aging

\section{Salt crystallization weathering}

To study the durability of consolidation materials against salt weathering, the laboratory samples were treated with a solution of sodium chloride $(\mathrm{NaCl}, 10 \%)$, this hygroscopic salt is the most permanent salt phase detected in most of the stone monuments and wall paintings in Egypt. The stone samples were coated with paraffin wax in all the sides expect of the top and the bottom, and then they lied on wooden panels and immersed in the saturated solution for 16-18 hours. After this step, samples were removed and let to dry in room temperature then they were put in an oven in temperature reached to $60^{\circ} \mathrm{C}$ for 8 hours with intervention for 2-4 hours in room temperature. This procedure was repeated for 17 cycles. Figure 2 shows laboratory models before and after artificial aging. 


\section{Experimental setup}

\section{Consolidation products}

Four commercial products were selected and subjected to tests as follows:

1. Wacker VP 1311 (1:9 in water): a concentrated silicone micro emulsion, water and solvent-free based on silane/siloxane which is used for the formulation of water-repellent protective.

2. Wacker $\mathrm{OH}$ (Stone strengthener): a ready to use product based on tetraethoxysilane (TEOS).

3. Paraloid B82 ( $3 \% \mathrm{w} / \mathrm{v}$ in toluene): a $100 \%$ acrylic co-polymer based on ethyl-methacrylate and methyl-methacrylate

4. Paraloid B67 (2.5\% w/v in acetone): a 100\% acrylic resin based on isobutyl methacrylate.

\section{Samples and application technique}

In order to prepare laboratory models similar to the archaeological murals, the results of the analytical techniques (XRD, FTIR,..etc.) were taken into consideration. The limestone specimens collected from El-Qurna mountain were cut in squared blocks $\left(10-10-3 \mathrm{~cm}^{2}\right)$, then, samples were plastered by a preparation layer consists mainly of gypsum and powder of limestone $(2: 1 \mathrm{w} / \mathrm{w})$ with thickness ranges from $200 \mu \mathrm{m}$ to $2 \mathrm{~mm}$, then they were painted with different pigments (red ochre, yellow ochre, calcium carbonates,...etc.). The organic binder used to fix the pigments was gum Arabic. Samples were treated with the consolidation products, and in order to have the greatest penetration of the consolidants, brushing was used to treat all the studied samples. The surface of some samples (scheduled to be treated with Paraloid B67 and B82) was saturated with the solvent and the consolidant solution was then applied. The application of solvent helped the solution to penetrate more deeply. The application of solvent and consolidant solution continued non-stop until the surface was saturated and did not accept any more consolidant solution. The treated samples were kept in horizontal position at room temperature and a controlled value of $50 \% \mathrm{RH}$ for two weeks in order to release all the solvent.

\section{Results and discussions}

\section{The mineralogical characterization of the weathered samples}

X-ray diffraction measurements of the archaeological stone samples showed that calcite $\left(\mathrm{CaCO}_{3}\right)$ is the predominant phase in all samples, with minor amounts of quartz $\left(\mathrm{SiO}_{2}\right)$ and halite $(\mathrm{NaCl})$, and traces of clay minerals (illite). XRD analysis of the preparation layers showed that they consist mainly of gypsum $\left(\mathrm{CaSO}_{4} 2 \mathrm{H}_{2} \mathrm{O}\right)$ with minor amounts of calcite and halite. Traces of quartz, anhydrite $\left(\mathrm{CaSO}_{4}\right)$, albite $\left(\mathrm{NaAlSi}_{3} \mathrm{O}_{8}\right)$, kaolinate $\left(\mathrm{Al}_{2} \mathrm{Si}_{2} \mathrm{O}_{5}(\mathrm{OH})_{4}\right)$, and illite.

\section{The morphological characteristics of the damaged samples}

Figure 3 shows SEM micrographs obtained on the damaged stones and plaster layers. SEM investigation of the damaged stone samples showed the crystallization of different salts and mainly sodium chloride (halite) in the stone matrix causing the disintegration and decomposition of the stone (Fig. 3a). Moreover, the SEM micrographs showed the erosion of calcite crystals due to weathering 
mechanisms, and also, crystals of clay minerals were also observed in structure of the stone (Fig. $3 b)$. The SEM micrograph obtained on the clay render showed the presence of chopped straw fibres beneath and on the surface (Fig. 3C). The investigation of the damaged plaster layers showed the loss of cohesion between particles and the crystallization of salts, mainly gypsum and anhydrite, in form of dense coat covers the surface (Fig. 3d).
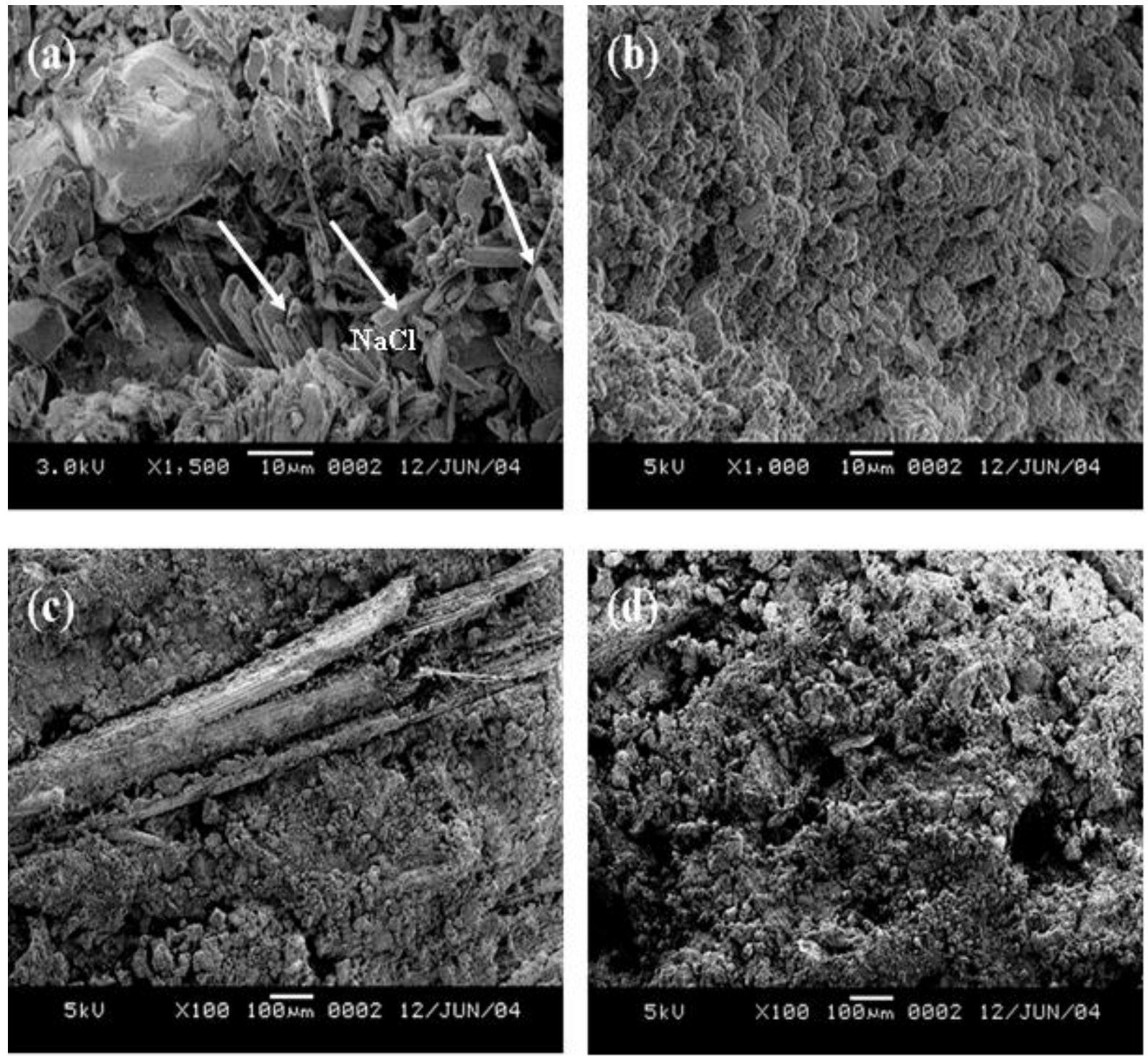

Figure 3. SEM micrographs of damaged stone and plaster layers. (a) Weathered stone and crystallization of many salts such as halite. (b) The loss of cohesion of the stone matrix due to the weathering process. (c) Chopped straw fibres beneath and on the surface of the clay render. (d) The precipitation of salt layer on the surface. 


\section{Evaluation of consolidation process}

\section{Visual observation and colorimetry}

Visual observations indicated that some consolidation products have changed the color of the samples. When the surfaces of the samples were treated with consolidation materials, they darkened, but after drying, the darkness of the surfaces decreased. In order to show the size of the color difference between the treated and untreated samples, the difference of color coordinates of brightness $\left(\Delta \mathrm{L}^{*}\right)$ and $\left(\Delta \mathrm{a}^{*}\right.$ and $\left.\Delta \mathrm{b}^{*}\right)$ in addition to the color difference $\left(\Delta \mathrm{E}^{*}\right)$ was used. $\mathrm{L}^{*}$ refers to the brightness, while $a^{*}$ and $b^{*}$ to the red-green and yellow-blue color, respectively. The $\Delta L^{*}$ value describes a change in brightness. Positive values of $\Delta \mathrm{a}^{*}$ and $\Delta \mathrm{b}^{*}$ indicate that the treated samples are more red and yellow, respectively, than the untreated samples. The chromatic variations induced by the applied products range in acceptable limits when parameter $\Delta \mathrm{E}^{*}$ is $\angle 5$ (Simionescu and Olaru 2009). The most significant decrease in lightness was observed with the application of Paraloid B67 followed with Paraloid B82. Other chromatic variations include a slight increase in yellow hues $\left(\Delta b^{*}\right)$ for the samples treated with Wacker $\mathrm{OH}$. Other chromatic variations include a slight increase in red $\left(\Delta \mathrm{a}^{*}\right)$ and yellow hues $\left(\Delta \mathrm{b}^{*}\right)$. Treatments with the acrylic co-polymers changed the color more than silane-based products as Wacker OH and Wacker VP 1311 changed the color the least. The order of the results from most color change to the least was: Paraloid B67 $\left(\Delta \mathrm{E}^{*}=4.2\right)$, Paraloid B82 $\left(\Delta \mathrm{E}^{*}=3.2\right)$, Wacker VP $1311\left(\Delta \mathrm{E}^{*}=2.7\right)$ and Wacker $\mathrm{OH}\left(\Delta \mathrm{E}^{*}=1.8\right)$ (Fig. 4a).

\section{The physical and mechanical properties of the samples}

The physical properties of the stone samples were determined. The bulk density showed value of $1.65 \mathrm{~g} / \mathrm{cm}^{3}$, while the porosity showed value $7.3 \%$, and the water absorption with value of $8.2 \%$. The mechanical properties of the stone samples were determined. The dry compressive strength of the samples showed value of $115.2 \mathrm{~kg} / \mathrm{cm}^{2}$, while the wet compressive strength of the samples showed value of $98.9 \mathrm{~kg} / \mathrm{cm}^{2}$.

\section{Contact angle measurements}

The results indicated that already after the first application of the coating, the wettability decrease is about $60 \%$; furthermore, the depletion of the water into the porous matrix prevails over the surface spreading. The contact angle itself presented an increase of about $50 \%$ already after the first application. This meant that a drastic decrease of the surface wettability is immediately induced by the application of the polymers. The highest value was recorded for Wacker VP1311 (110 $)$ (Fig. 4b).

\section{The physical and mechanical properties after treatment}

Figure (4c) shows diagram of porosity and water absorption measured on stone samples after treatment. The porosity of samples after treatment showed values: samples treated with Paraloid B82 $=2.31 \%$, samples treated with Paraloid B67 $=2.45 \%$, samples treated with Wacker VP 1311 $=3.12 \%$, samples treated with Wacker $\mathrm{OH}=3.17 \%$. The water absorption of treated samples decreased significantly after treatment, samples treated with Paraloid B82 $=3.49 \%$, samples treated with Paraloid B67 $=2.52 \%$, samples treated with Wacker VP $1311=3.72 \%$, samples treated with Wacker $\mathrm{OH}=2.62 \%$. The durability of the treated samples was increased dramatically after treatment as shown in Figure 4(e). The samples treated with Paraloid B82 showed a dry compressive strength $=153 \mathrm{~kg} / \mathrm{cm}^{2}$, while samples treated with Paraloid B67 showed a dry compressive strength 
$=147 \mathrm{~kg} / \mathrm{cm}^{2}$. Silane-based products of Wacker $\mathrm{OH}$ showed a dry compressive strength $=139$ $\mathrm{kg} / \mathrm{cm}^{2}$, while Wacker VP 1311 showed a dry compressive strength $=131 \mathrm{~kg} / \mathrm{cm}^{2}$.

\section{Study using scanning electron microscopy (SEM)}

Figure (5) displays SEM micrographs obtained on the treated samples. Tiny pieces from the inner areas of the consolidated models were cut and investigated (the average depth of cutting from the outer surface of samples were approximately $23 \mathrm{~mm}$ ). SEM investigation is reported to show the surface morphology of the samples before and after the application of consolidation products. In the case of Wacker VP 1311, the water emulsion can create "islands" in the surface and a dense coat of the resin was formed between the crystals (Fig. 5a). After treatment with Wacker OH, it was observed that the microstructure created within the stone by the deposition of the polymeric material formed a homogenous film and a new network was created, also the cohesion of grains was increased in addition it smoothed the roughness of the surface (Fig. 5b). The main effect after the acrylic co-polymers (Paraloid B67 and B82) was the formation of a dense coat covers the grains and affects seriously the porosity of the stone. Using Paraloid B67, a dense surface layer was formed that alters dramatically the stone's morphology; the occlusion of pores with diameter in the range of few microns is observed, in addition, micro-cracks were also observed (Fig. 5c). Paraloid B82 deposited between the grains and grains are covered with the polymeric material (Fig. $5 \mathrm{~d}$ ).

\section{Evaluation after salt weathering}

After salt weathering, samples were subjected again to color measurements to detect any change in their appearance. The chromatic variations induced by the artificial ageing on the treated surfaces showed that the most significant decrease in brightness was observed with samples treated with Paraloid B67. Other chromatic variations include a slight increase in red $\left(\Delta \mathrm{a}^{*}\right)$ and yellow hues $\left(\Delta \mathrm{b}^{*}\right)$ were also detected; the highest increase in the yellow hue was observed in the case of Paraloid B67 and Paraloid B82. Treatments with Paraloid B67 changed the color more than other consolidants, while the least color change was induced by Wacker $\mathrm{OH}$. The order of the results from most color change to the least was: Paraloid $B 67\left(\Delta E^{*}=5.32\right)$, Paraloid $B 82\left(\Delta E^{*}=4.21\right)$, Wacker VP1311 $\left(\Delta \mathrm{E}^{*}=3.16\right)$ and Wacker $\mathrm{OH}\left(\Delta \mathrm{E}^{*}=2.8\right)$. After salt weathering, the porosity of samples was increased (Fig. 4d), it reached for samples treated with Paraloid B82 to 3.1\%, for Paraloid B67 $=2.98 \%$, for Wacker VP $1311=3.67 \%$, and for samples treated with Wacker $\mathrm{OH}=3.77 \%$. The water absorption of treated samples decreased significantly after treatment, samples treated with $\mathrm{Pa}$ raloid B82 $=3.49 \%$, samples treated with Paraloid B67 $=2.52 \%$, samples treated with Wacker VP $1311=3.72 \%$, samples treated with Wacker $\mathrm{OH}=2.62 \%$. The mechanical properties after salt weathering were slightly decreased (Fig. 4f). Samples treated with Paraloid B82 showed a dry compressive strength $=140 \mathrm{~kg} / \mathrm{cm}^{2}$, while samples treated with Paraloid B67 showed a dry compressive strength $=135 \mathrm{~kg} / \mathrm{cm}^{2}$. Silane-based products of Wacker $\mathrm{OH}$ showed a dry compressive strength $=132 \mathrm{~kg} / \mathrm{cm}^{2}$, while Wacker VP 1311 showed a dry compressive strength $=125 \mathrm{~kg} / \mathrm{cm}^{2}$. SEM investigation was used once again to examine the stability of the consolidation products after salt weathering (Fig. 6). After salt weathering, the samples showed modifications in their morphology. In the case of Wacker VP 1311, the consolidating material has surrounded the particles and coated the surfaces of the pores (Fig. 6a). Wacker $\mathrm{OH}$ was mainly deposited to the inner pore wall leaving a smooth surface on the grains (Fig. 6b). Sample treated with Paraloid B67 showed that the pores are still mostly filled with the polymeric material (Fig. $6 \mathrm{C}$ ). The surface of the sample treated with Paraloid $B 82$ became more smoothed and the polymer materials still covering the surface with a dense coat (Fig. 6d). 

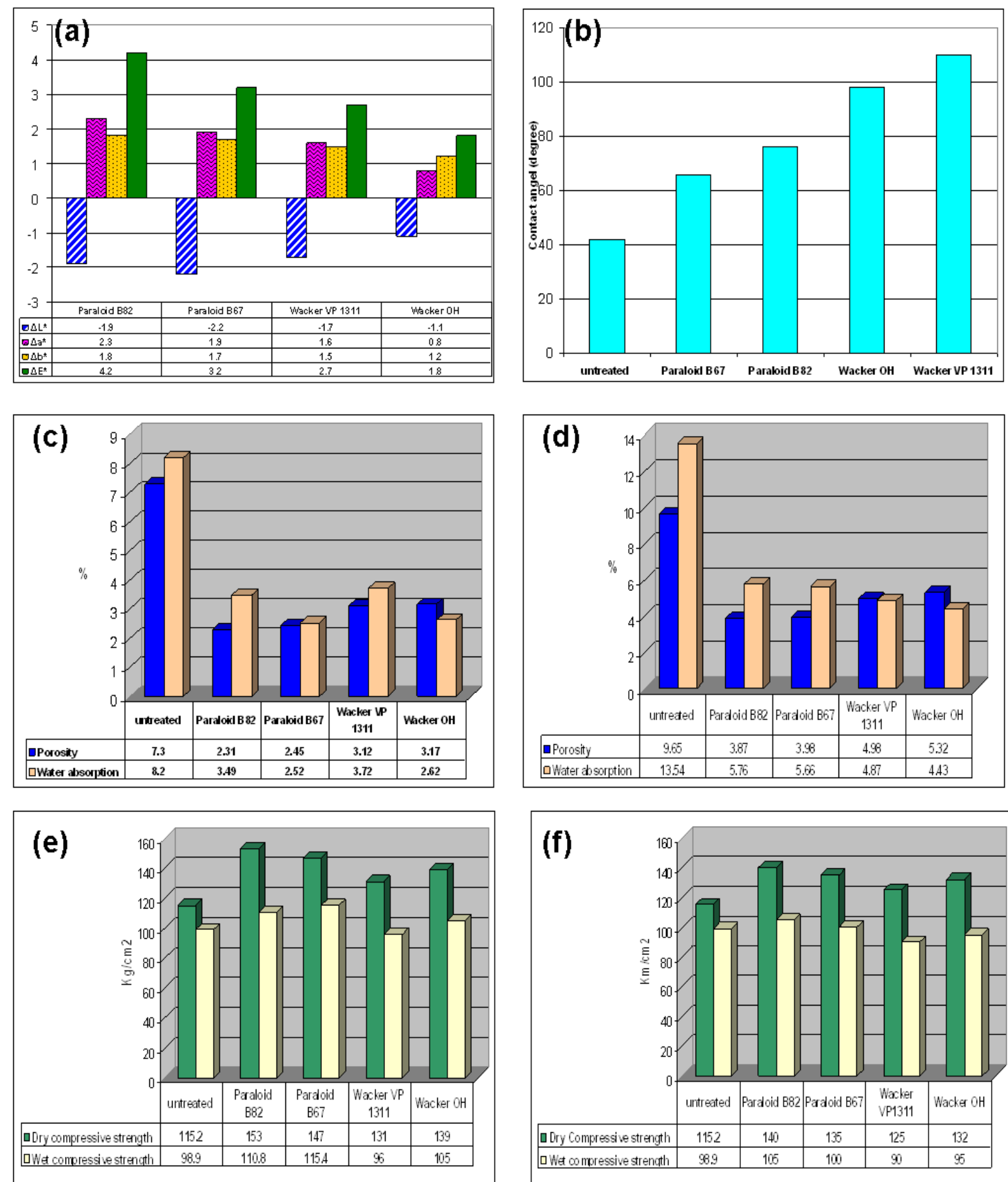

Figure 4. (a) The chromatic parameters obtained after treatment by consolidation products. (b) Contact angle values before and after treatment of the samples with the consolidation products. (c) Values of porosity and water absorption (\%) of the studied samples before and after treatment. (d) Values of porosity and water absorption (\%) of the untreated and treated samples after salt weathering. (e) The mechanical properties (dry and wet compressive strength) of the studied samples before and after treatment. ( $f$ ) The mechanical properties (dry and wet compressive strength) of the untreated and treated samples after salt weathering 

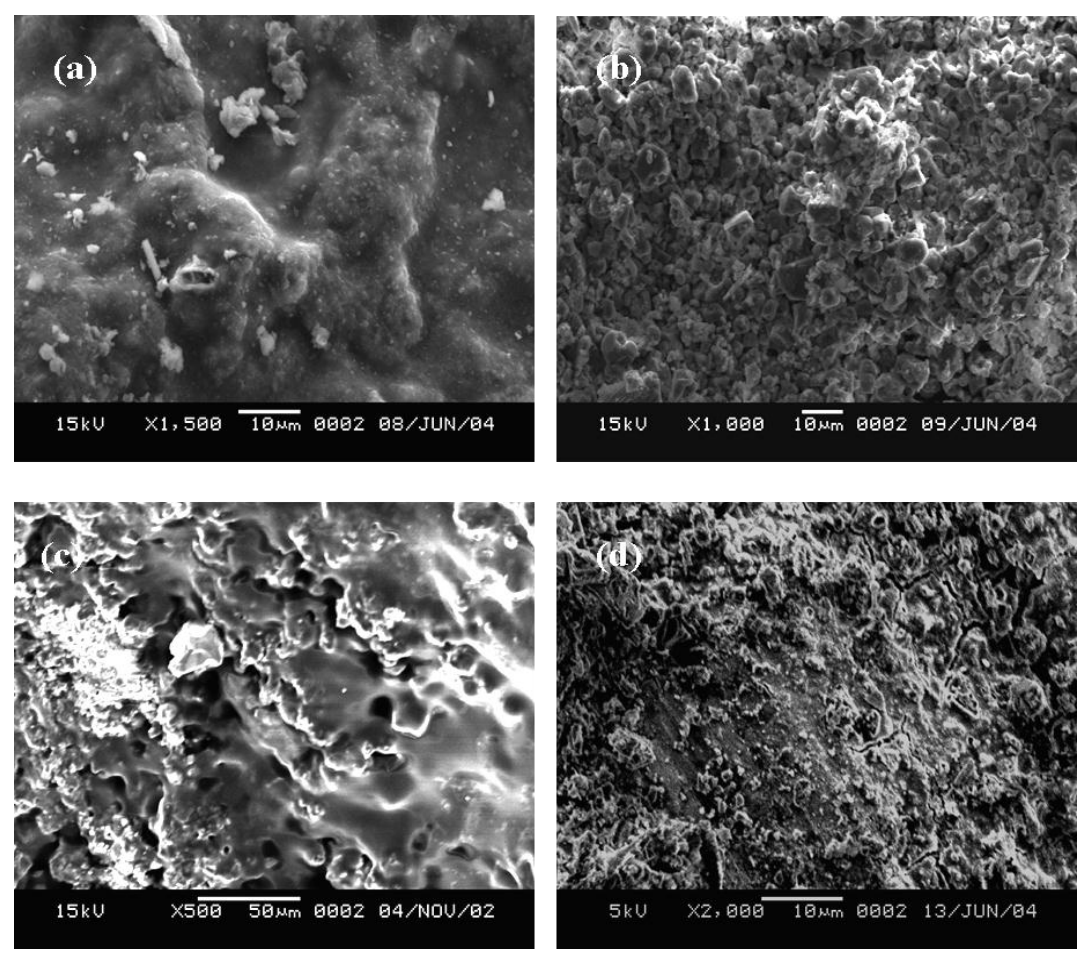

Figure 5. SEM micrographs of stone samples after treatment with the consolidation products. (a) Sample treated with Wacker VP 1311. (b) Sample treated with Wacker OH. (c) Sample treated with Paraloid B67. (d) Sample treated with Paraloid B82.
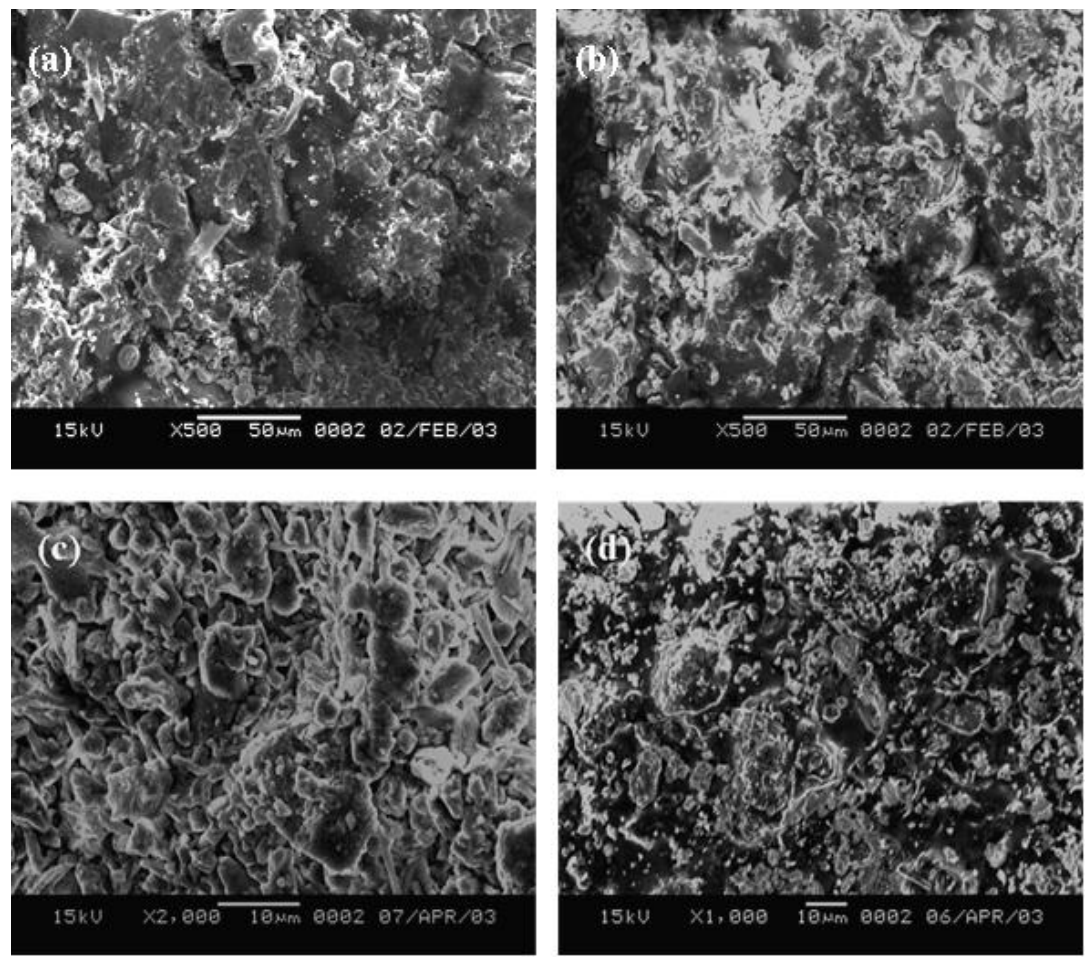

Figure 6. SEM micrographs of the treated stone samples after salt weathering. (a) Sample treated with Wacker VP 1311. (b) Sample treated with Wacker OH. (c) Sample treated with Paraloid B67. (d) Sample treated with Paraloid B82. 


\section{Conclusions}

Strategies to protect and conserve cultural heritage internationally have been successfully developed over the last decades through UNESCO and a large number of non governmental organizations (NGOs) and foundations (Arizpe 2000). In this work, the effectiveness of four polymeric coatings used for the protection of damaged Egyptian wall paintings from the tomb of Ameneminet (TT277), El-Qurna necropolis, Upper Egypt, has been evaluated. The tested products were: Wacker VP 1311, Wacker OH (Stone strengthener), Paraloid B82, and Paraloid B67. The evaluation of the consolidation process was performed using the visual observation, scanning electron microscopy (SEM), contact angle values, colorimetry and determining the physical and mechanical properties.

The laboratory tests on the treated stone samples indicated that some chromatic variations were induced, it was found that the variations range was in acceptable limits when parameter $\Delta \mathrm{E}^{*}$ is $<4$. In comparison with other products tested in this study, Wacker $\mathrm{OH}$ changed the color the least, it formed a homogenous form inside the stone matrix and showed a good resistance against salt weathering. The highest contact angle value was recorded for Wacker VP 1311, and this is attributed mainly to its chemical characteristics. In conclusion, Wacker $\mathrm{OH}$ can be applied to improve the durability of the inner matrix and Wacker VP 1311 to increase the water repellency. To fix the detached plasters to the painting the injecting by Plextol B500 (an acrylic emulsion) (2:1 with water/ethanol 4:1) was performed. First, the paint surface itself was pre-wetted with a white spirit, thus avoiding unwanted staining of the paint surface. For paint flakes, the surface was prepared by the application of white spirit to the surface, then Plextol B500 (in water with 10\% (v/v) ethanol) was applied behind the flake which was gently pressed back into place with a spatula. The result of this is impressive. Furthermore, the preventive conservation based mainly on control of the microclimate inside the ancient tombs will be of importance to decrease any damage in future.

\section{Acknowledgments}

The author would like to extend his deep thanks to the staff of the local department of restoration at ElQurna office, Luxor for their assistance through this field study and collection of samples.

\section{References}

AHMADI, Sh. (2008). Adobe conservation: Evaluation of Silicone and Acrylic consolidants. MSc. thesis, Department of Art, Queen's University, Kingston, Canada.

AMOROSO, G., FASSINA, V. (1983). Stone Decay and Conservation, atmospheric pollution, cleaning, consolidation, and protection. Elsevier Science Ltd.

ARIZPE, L. (2000). "Cultural Heritage and Globalization". In Values and Heritage Conservation, Conservation Research Report, Avrami, L and Mason, R. (eds.). Los Angeles: The Getty Conservation Institute, 32-37.

ARNOLD, A., ZEHNDER, K. (1987). "Monitoring wall paintings affected by soluble salts". In: The conservation of wall paintings, Proceedings of a symposium organized by Courtauld Institute of Art and the Getty Institute, London, July 13-16, London: Cather, Sh. (Ed.), 103-135.

BRUS, J and KOTLIK, P. (1996). "Conservation of stone by mixtures of Alkoxysilane and acrylic polymer". Studies in Conservation, 41: 109-117. 
CHIARI, G, RIGONI, M, JOFFROY, Th. V. (1992). "Ethyl silicate Treatments and Humidity". In Proceedings of the 7 th international congress on deterioration and conservation of stone, Delgado-Rodrigues, J., Henriquez, F and Jeremias, J.T. (eds.), Lisbon, October 24-29, 422-426.

CLIFTON, J.R and FROHNSDROFF, GJC (1982). "Stone-Consolidating Materials, A status Report". In Conservation of Historic stone Buildings and Monuments, Washington DC: National Academy Press, 287-311.

CNUDDE, V., DIERICK, M., VLASSENBROECK, J., MASSCHAELE, B, LEHMANN, E, JACOBS, P, VAN HOOREBEKE, L. (2007). "Determination of the impregnation depth of siloxanes and ethylsilicates in porous material by neutron radiography". Journal of Cultural Heritage, 8: 331-338.

DELGADO RODRIGUES, J. (2001). "Consolidation of decayed stones: A delicate problem with few practical solutions". In Historical Constructions, Possibilities of numerical and experimental techniques, Proceedings of the 3rd International Seminar, 7-8-9 November 2001. Lourenço, P.B and Roca, P. (Eds.), Guimarães: University of Minho, 3-14.

FAVARO, M., MENDICHI, R., OSSOLA, F., SIMON, S., TOMASIN, P., VIGATO, P.A. (2007). "Evaluation of polymers for conservation treatments of outdoor exposed stone monuments. Part II: Photo-oxidative and salt-induced weathering of acrylic silicone mixtures". Polymer Degradation and Stability, 92: 335351.10.1016/j.polymdegradstab.2006.12.008

FERREIRA PINTO, A.P., DELGADO RODRIGUES, J. (2008). "Stone consolidation: The role of treatment procedures". Journal of Cultural Heritage, 9: 38-53. http://dx.doi.org/10.1016/j.culher.2007.06.004

GRISSOM, C.A. (1996). "Evaluation overtime of an Ethyl silicate consolidant applied to ancient lime plaster". Studies in Conservation, 44: 113-117.

GUILLAUME, A., PIAU, J-M. (2003). "Stability of the tomb of Rameses II (Valley of the Kings, Luxor, Egypt): Numerical models and reality". Bulletin des Laboratoires des Ponts et Chaussées, 242: 15-47.

HORIE , C.V. (1997). Materials for Conservation. Oxford, Butterworth-Heinemann. 1997.

KAMIL, J. (1976). Luxor: A Guide to Ancient Thebes, (2nd ed.), London: Longmans.

KEUNE, K., BOON, J.J., (2005). "Analytical imaging studies clarifying the process of the darkening of vermilion in paintings". Analytica Chimica Acta, 77 (15): 4742-4750.

MANOUDIS, P., PAPADOPOULOU, S., KARAPANAGIOTIS, I., TSAKALOF, A., ZUBURTIKUDIS, I., PANAYIOTOU, C. (2007). "Polymer-Silica nanoparticles composite films as protective coatings for stone-based monuments". Journal of Physics: Conference Series, 61: 1361-1365. doi:10.1088/1742-6596/61/1/269

MANOUDIS, P., KARAPANAGIOTIS, TSAKLOF, A., ZUBURTIKUDIS, I., PANAYIOTOU, C. (2008). "Superhydrophobic Composite Films Produced on Various Substrates". Langmuir, 24: 11225-11232.

MAREY MAHMOUD, H. (2010:2). "Archaeometric and petro-mineralogical remarks on damaged Egyptian wall paintings, El-Qurna necropolis, Upper Egypt". Archeometriai Mühely, 149-156. http://epa.oszk.hu/00800/00846/00020/pdf/Archeometriai_Muhely_EPA00846_10-02-HMM.pdf

PEL, L., HUININK, H., KOPINGA, K. (2002). "Ion Transport and Crystallization in inorganic Building Materials as studied by Nuclear Magnetic Resonance". Applied Physics Letters, 81:1(5): 2893-2895.

PRICE, C.A. (1996). Stone Conservation: An Overview of Current Research. Los Angeles: The Getty Conservation Institute.

RILEM (1980). "Tests Defining the Structure", Materials and Construction, 13: 73. 
RIZZO, G., ERCOLI, L., MEGNA, B. (2009). "Effectiveness of Preservative Treatments on Coloured Ruditic Building Stones", Strain, 45 (5): 424-432. DOI: 10.1111/j.1475-1305.2008.00547.x Published

ROBERT, C., CRESPY, A., BASTIDE, S., LOPEZ- CUESTA, J-M., KERBOEUF, S., ARTIGUE, C., GRAD, E. (2004). "Adhesive properties of silicone polymers on some typical opto-electronic substrates: influence of the network density". International Journal Adhesion and Adhesives, 24: 55-68. http://dx.doi.org/10.1016/S01437496(03)00100-3

RODRIGUEZ-NAVARRO, C., DOEHNE, E. (1999). "Salt Weathering: Influence of Evaporation rate, super saturation and crystallization Pattern". Earth Surface Processes and Landforms, 24: 191-209.

SAID, R. (1960). The Geology of Egypt, New York: Elsevier publishing company.

SIMIONESCU, B., OLARU, M. (2009). "Assessment of siloxane-based polymeric matrices as water repellent coatings for stone monuments". European Journal of Science and Theology, 5 (1): 59-67.

TORRACA, G. (1988). Porous Building Materials: Materials Science for Architectural Conservation. 3rd Edition. Rome: ICCROM.

XU, F., LI, D., ZHANG, H., PENG, W. (2012). "TEOS/HDTMS inorganic-organic hybrid compound used for stone protection". Journal of Sol-Gel Science and Technology, 61 (2): 429-435. DOI: 10.1007/s10971-011-2643-0

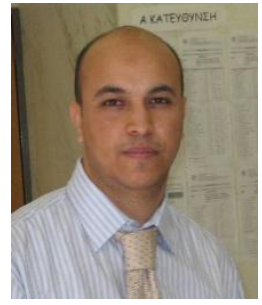

\section{Dr. Hussein Hassan Marey Mahmoud}

marai79@hotmail.com

Lecturer (PhD) at the Department of Conservation, Faculty of Archaeology, Cairo University, Egypt. Master degree in Conservation of ancient wall paintings from Cairo University. Doctoral degree from the Faculty of Engineering, Aristotle University of Thessaloniki, Greece.

Artículo recibido el 14/01/2012

Artículo aceptado el 21/05/2012 